\title{
Pericardial Wall
}

National Cancer Institute

\section{Source}

National Cancer Institute. Pericardial Wall. NCI Thesaurus. Code C127672.

The wall of the pericardium, comprising the following tissue layers: the fibrous pericardium; the parietal and visceral layers of the serous pericardium. 